\title{
From Biography to Theory: the role of Anna Freud in the emergence of the "adolescent process"
}

\author{
Florian Houssier
}

Psychologist, Psychoanalyst, President of the Collège International de L'Adolescence (CILA), Professor of Clinical Psychology and Psychopathology at the University of Paris-North: Transversal Research Unit Psychogenesis and Psychopathology (UTRPP), Villetaneuse, Sorbonne Paris Cité (SPC).

Received: September 22, 2016; Accepted: October 18, 2016; Published: October 24, 2016

*Corresponding author: Florian Houssier, Psychologist, Psychoanalyst, President of the Collège International de L'Adolescence (CILA), Professor of Clinical Psychology and Psychopathology at the University of Paris-North: Transversal Research Unit Psychogenesis and Psychopathology (UTRPP), Villetaneuse, Sorbonne Paris Cité (SPC).E-mail: houssier.florian@gmail.com

\section{Abstract}

Some aspects of Anna Freud's life reveal the existence of specifically adolescent conflicts, which can be tied to some of her theoretical and clinical discoveries in the field of adolescent psychoanalysis. Her historical input in the gradual construction of a theoretical corpus on adolescence has often been ignored. These links between biography and theory gave rise to a movement of conceptualisation making it possible to develop a psychoanalytic metapsychology of adolescence: indeed, emerged such notions as asceticism, intellectualisation in relationship with anorexia and the struggle against the genitalisation of the adolescent body.

Today, the Annafreudian school of thought has remained the main source of investigation and theoretical transmission of what is now called the adolescent process.

Key words: Anna Freud; Biography; Masculinity complex; Adolescence; Beating fantasies; Transmission

\section{Introduction}

Anna Freud is most often associated with child analysis, frequently in the context of her rivalry with Melanie Klein. This article addresses a different issue, that of adolescence, a field untouched by the battle between their opposing views. Our perspective is the following: certain aspects of Anna Freud's life reveal the existence of specifically adolescent conflicts, which can be related to some of her clinical and theoretical discoveries in the field of adolescent psychoanalysis. Adolescence is one of the threads discreetly linking her life, beginning with her own analysis, and later work. Much has been said and written about her close ties with her father and the contradictions of Annafreudian theory, but her historical input in the construction of a theoretical corpus on adolescence, once the "Cinderella of psychoanalysis" [15], has largely been forgotten.

Let us be clear: our aim is not to retrace Anna Freud's life in detail or review her theories, but to suggest a link between biography and theory, a link that laid the foundations for the elaboration of a metapsychology of adolescence. We wish to study the very close relationship between private life and theoretical elaboration, while avoiding the pitfalls of psychobiography, too often exclusively centred on the infantile. Our main source on Anna Freud's life is Elisabeth Young-Bruehl's biography (1988), which provides an acute insight into her adolescence. Young-Bruehl considers that Anna Freud theorised on the basis of her own understanding of herself. Indeed, her self-analysis yielded several important clinical notions: altruistic surrender, asceticism, intellectualisation, daydreaming and anorectic disorders in the context of the struggle against genitalisation during adolescence.

In order to begin our approach to this difficult context linking personal life, psychoanalysis, and theoretical elaborations in a complex web of ramifications, we will consider the following points: 1 . The development of the psychoanalysis of adolescence began with Freud's founding work on the "Transformations of Puberty" (1905). 2. Freud began to analyse his daughter at a time when she was still working through her adolescent conflicts; 3 . Anna Freud's first paper (1922), based on her own case, reflected these issues. The paper was directly linked to her analysis and dealt with personal issues raised by adolescence. 4. In her most important work of the Viennese period (Freud, A. 1936), one case can be considered autobiographical, a self-analysis of the woman she had then become, in other words a woman who found a way of sublimating her infantile and adolescent conflicts. A long chapter of the work is devoted to adolescence, probably the most complete essay on the topic at that time: it is the first clinical and theoretical study of what was later called, particularly in France and in Anglo-Saxon countries, the 'adolescent process', a generic term whose relevance is still questioned today (André, J. Chabert C, 2010).

\section{From the "black devil" to Antigone: a troubled adolescent}

\section{Between jealousy and identification}

Anna was born in 1895, the third daughter and youngest of Sigmund and Martha's six children. She was an unwanted child, and to make matters worse, Freud wrote to Fliess, anticipating 
his daughter's future masculinity complex: "You will not have any objections to my calling my next son 'Wilhelm'! If he turns out to be a girl, she will be called 'Anna' [44]. Anna Freud's internal conflicts touched upon two realms, one more discreet and tied to her rebellion against her mother, whom she felt to be either intrusive or neglectful, while the other concerned her passionate love for her father.

She felt rejected by her older siblings, who considered her as "one too many", and had trouble asserting herself. Her father would sometimes comfort her and congratulate her for her undemanding attitude. The pleasure she felt at receiving her father's approval was so great that nothing else was of any importance to her.

Anna was brought up by her governess Josefine, for whom she was a sort of favourite and only child, and found in her own childhood one of her central themes - the fear of being abandoned, expressed in terms of a fear of "losing and being lost" (Freud, A, 1967). She associated the feeling of being lost - not only metaphorically- with the ambiguity of her parents' feelings for her, her mother's distracted attention: "You lost me!" cried little Anna reproachfully to her mother upon reuniting with her.

Despite her jealousy, she identified with Mathilde, her older sister and ideal child of the Freud family. The tensions in her relationship with Sophie, whom she called "the family's little angel", and whose beauty she envied, were quite strong, especially as Sophie was devoted to their mother. What Freud admired in Anna, however, was not the feminine charm he found in her sisters, but her spunky and cheeky character, and even her meanness. Before she became his Antigone, Anna was his "black devil" with whom he exchanged grunts as he entered the dining-room to lunch after the morning's work. From her early adolescence on, she sat in on the debates of the Wednesday society, listening with fascination; in 1909, she was very unhappy at being considered too young to accompany her father to the United States.

Anna was quite annoyed by mother's "secretiveness" - a character trait which later became a theme of her 1936 book (Freud A., 1936). Indeed, Martha, probably concerned about her daughter's anxiety, would hide such things from her as the dates of her examinations, or upcoming appendectomy. Anna entered the hospital not knowing that she was going to be operated on, and developed various symptoms shortly after. She was then thirteen.

\section{Shared ambivalence}

After the appendectomy, she continued to experience forms of psychological distress, such as the feeling of being exhausted or stupid. She later tied these feelings to her daydreams accompanying her masturbatory fantasies. Eating disorders also appeared in early adolescence, reminiscent of the greediness described by Freud with the famous "strawberry" dream [18]. In the early 1910s, weakened by her constant illnesses, she lost weight. From Merano, where she was convalescing, Anna wrote home every day, especially to her father, reporting every pound she gained and telling him that she wanted him near her, that she would like him to continue calling her his "black devil". In his answers, Freud tried to reason with her, criticizing her tendency to be too passionate and obstinate. In one letter, he told her that she need not write every day, and asked her to take care of herself, because she was "still quite young" [44].

In 1913, after her sister Sophie's wedding - among the siblings, Sophie was her main rival for their father's love - Freud wrote to Anna that she was "overzealous, restless and unsatisfied because [she has] run away like a child from many things of which a grown-up girl would not be afraid" (ibid., p. 59). In the same letter, Freud added: "We will notice a change when you no longer withdraw from the pleasures of your age but gladly enjoy what other girls enjoy" thus noting that she was "removed from [her] own life" (ibid.). Anna criticized her own tendency to daydream, during which she would withdraw into intense erotic fantasies, instead of looking for an object in reality, outside the family. Freud then voiced his and Martha's hopes for their daughter, i.e. "normal femininity" (ibid.).

In 1915, as she was preparing for the schoolteacher's examination, Freud expressed the wish to keep his daughter near him. He found her to be "a charmer, more delightful than any of their other children" (letter to Ferenczi, quoted by Young-Bruehl, op.cit, p.72); in another letter to Ferenczi, he admitted being "in need of signs of youthfulness and vigor", adding, with insight, that his daughters Sophie and Anna "thoroughly satiate[d] his libido". "The little one is also an extraordinarily dear and interesting creature", he wrote, a consolation for the thought that, as he put it, that "now [he has] left only [his] two old ones", i.e. his wife and sister-in-law (ibid.). Freud's ambivalence lasted until he fell ill with cancer. In 1921, he wrote to Max Eitingon that he would also like her to "exchange her attachment to her old father for some more lasting one". (ibid. p.111).

According to Young-Bruehl, Martha Freud's lack of support for her husband's profession, not to mention her negative opinion of psychoanalysis, made it possible for her youngest daughter to adopt the role of companion in her father's work and in the end, in his life as well. She saw her mother as someone who had "lost her", someone who did not take care of her, unlike her other objects of feminine identification, Loe Kann or Lou Andreas-Salomé, whom she saw as her adoptive mothers in the same way as she herself had been for her nephew Ernst. We observe a splitting of maternal figures: on the one hand, Martha, whom she considered intrusive and abandoning, an object of anger - sometimes directed against her aunt Minna who had the privilege of travelling alone with Freud. On the other hand, the substitutes of Josefine, in particular the idealized mother figure represented by Lou Andreas-Salomé. Replacing Martha, Lou formed with Freud an analyst-parent couple sharing their "Daughter-Anna" (ibid, p.112), an image of fertility by way of the intellect, something strongly invested by all three.

\section{Analysis or "something to help myself"}

One of the reasons that led Anna to ask her father for an analysis was her inability to understand the reasons for her persistent feeling of unease, in particular her "psychasthenia", as it was then 
termed, as well her anorexia and masturbatory tendencies. She expressed this in a letter written to him after Sophie's wedding in 1913: "I would like to know, so that I can do something to help myself" adding in a postscript that "anyway, she had no secrets for him" (ibid. p.58). In her daydreams, she generally imagined herself as a boy, as she felt that she was not feminine and pretty enough, not as pretty as Sophie. Masturbatory satisfaction was produced by the image of a young boy, beaten or humiliated by a dominating man, a figure of authority. Only in 1922 did a woman begin to play a central role in her daydreams, as she confided to Lou Andreas-Salomé: "it was even a love story" [42].

At the age of 23 , as she began her first analysis, she went back to writing poems, an extension of what she called her "nice stories" and daydreams. Another consequence of her analysis was that "mostly dire things [happened] in her dreams - killing, shooting or dying", as she wrote to her father in 1919 [44]. Her adolescent distress and infantile conflicts surfaced: the nice stories were replaced by violent fantasies. Her "unruly ego" rose to the surface as well as severely repressed masturbation wishes. She began to tell herself stories again at night to fall asleep. Her unrequited quest for love found a compensation as she imagined herself as a male hero, earning "glory by the sword" and causing the envy of both young and old. The idea of potential renunciation emerged, a foreshadowing of future sacrifice: glory and success in exchange for relinquishing a life of love and happiness. The thought came to her that she might have found love "had she not been distracted by 'other thoughts' and turned in on herself" (ibid, p.95).

A struggle then developed between the beating fantasies, as a means to attain direct masturbatory satisfaction, and the "nice stories", a more sublimated outlet for the more repressed drives. The passage from daydreaming nice stories to writing them down was a first step towards sublimation, later developing into a passion for writing psychoanalytic articles or books. As she wrote in her first autobiographical article (Freud A., 1922), she drew pleasure not so much from the content of the stories, but from the actual act of writing which provided indirect libidinal satisfaction, with a narcissistic aim: to satisfy her ambition, renounce repressed genital pleasure and devote herself to the pleasure given to others. The vicarious wish of her fictitious patient was a first step towards developing the concept of altruistic surrender (Freud A, 1936). This "surrender" includes an essential component: the transformation of a solipsistic, narcissistic activity into a social activity, i.e. involving an object relation. We can also see here her desire for recognition and wish to be admired by her father in order to obtain his love. Through her masculine identification, she avoided greater oedipal guilt, but her conflict concerning her sexual identity remained intense.

\section{Being (a) double}

In 1922, the year she became a member of the Vienna Psychoanalytic Society and was finishing her first analysis, Anna Freud was beset by a typical adolescent conflict: whether to leave or remain in the family home. She thought of moving to Berlin, where she had a few friends, to begin her practice as a child psychoanalyst, but her father's cancer suddenly brought an end to her desire for independence. "Her adolescent turn outside of her family for friendship and love was still in course when she was faced with her father's illness in 1923", writes Young-Bruehl (op.cit., p.192). Her father clearly wished her to stay with him, a wish echoed by Anna: "You're right", she wrote to Lou AndreasSalomé, "I wouldn't leave him now under any circumstances" (ibid. p.118). Freud later (in 1935) confided to Lou that "I of course rely more and more on Anna's care, just as Mephistopheles once remarked: 'in the end we depend on the creatures we made'. In any case it was very wise to have made her" (Pfeiffer, 1972, p.209). Anna Freud was bonded to her father, and she confided in Dorothy Burlingham, who became her best friend during the 1920 s, that "as far as she [could] see, "being in love is never really enjoyable" (Young-Bruehl, op.cit., p.192).

In 1925, as her friendship with Eva Rosenfeld was still very strong, she confided to her that when her father was being treated for cancer, she was cast back into her adolescent condition, before her analysis, devoting most of her time to poetry, daydreaming, and weaving (ibid., p.135). "These two weeks", she wrote, "I have been living as I did before I was an analyst and before you and Dorothy knew me: with Rilke poems and daydreams and weaving" [31]. One of the main focuses of her treatment was thus the resolution of her adolescent conflicts, and the persistence of her masturbation fantasies seems to be the link between her two analyses.

In 1924, a dispute broke out between Otto Rank and Freud, and the latter agreed to let his daughter take over Rank's job as secretary of the Vienna Psychoanalytic Society. Her wish to take the place of a man, a wish she had so fully expressed in her daydreams, was thus fulfilled (Dyer, 1983) in the context of an unshakeable oedipal bond.

Indeed, when her father suggested in 1924 that she take up her analytic work with him again, she accepted gratefully, in particular because of the intrusive daydreams and beating fantasies that still plagued her. This time, having become an analyst herself, she understood the "temptations to untruthfulness" tied to her analyst being her father (Young-Bruehl, op.cit., p.123). Among the facts she concealed from her father/analyst was the emergence of her feelings for Dorothy Burlingham. Her feeling of dependence and her desire to have the Burlingham children and their mother for herself, in the same way as her onanistic temptations, resulted in a feeling of shame. Although she could confess her masturbatory desires to her father, she could not tell him about her growing attachment to the Burlingham family, which he nevertheless soon discovered.

However, this solution to her drive impulses could only last if the relationship remained platonic. Anna Freud's masculinity complex could be resolved through having obtained something children as a penis substitute- and a friend, Dorothy Burlingham, who represented several figures, though without genuine rivalry, the equivalent of a mother and a loving and docile sister. She thus found herself a substitute family, even though it was difficult for her, and for the four Burlingham children who soon became her 
patients, to play the double role of both substitute parent and analyst. The sense of ideal friendship fuelled in both women the fantasy of being twins, which echoed the fact that Dorothy's older sisters were twins. This extended family situation, where family and analytic ties were intertwined, repeated her own analytic experience (Houssier, 2010).

Her platonic relationship with Max Eitingon was also marked by loss and renunciation, themes which are ever present throughout her life and work. Max having given her up, the experience rekindled her perception of disappointing attachments, which she both sought and feared. At the same time, her relationship to her women friends became "mirror relationships", showing strong a narcissistic identification, the other and the self merging into a single person. This tendency became quite explicit, as Anna wrote to Eva Rosenfeld: "Now, we know: you are me and I am you" (Young Bruehl, p.cit. p. 136).

Taking this phrase out if its context, two complementary hypotheses emerge: that of sublimated love; or the language of passionate, yet brief adolescent friendships. On the personal side, the notion of altruistic surrender defined by Anna Freud (1936) seems closer to a struggle against her sexual and aggressive drives. The spirit of sacrifice, living a vicarious life, asceticism are reflections of a feeling of loss of Ego, a sense of being absent to herself, which she complains about in her letters to Eva Rosenfeld. This tendency to identify with others is very present in her relationship with her father: "When he is depressed, I am too" (Heller, 1992, p. 143). Her relationship with Dorothy Burlingham made it possible for her to reverse identifications and change places, enabling to her to feel like a mother or, as Kata Levy wrote to her, an older sister.

\section{An extended family}

The Freuds and Burlinghams were very close, gradually becoming an extended family, to the extent that Freud wrote to Ludwig Binswanger in 1928 of a "symbiosis" between the two families (Burlingham, 1989, p. 192). Through her friendships, first with Eva Rosenfeld, and especially with Dorothy Burlingham, Anna Freud found a compromise solution to her internal conflicts. These two substitute mothers enabled her to satisfy her masculinity complex, because they loved her like a sister, acknowledging her feminine part which she repressed through asceticism. E. Hitschmann considers that Anna Freud's theory on defence mechanisms, in particular during adolescence, can be linked to her position of sexual asceticism (Ibid, p.210). Her taste for intellectual pursuits, through her interest in her father's theories and her love of writing, are echoed in her theorisation of intellectualisation during adolescence (Freud A., 1936).

In December 1927, in a letter to Lou Andreas-Salomé, Freud wrote that "Anna is splendid, good, and intellectually independent, but [has] no sexual life. What will she do without her father, [i.e when I am gone?]" (Burlingham, op.cit. p. 210.). Her female friendships seemed like pale substitutes to him. In 1935, he once again expressed concern about what would become of her when he died. "What will she do when she has lost me? Will she lead a life of ascetic austerity?" (Pfeiffer, 1972, p.204).
However, the intense friendship she developed with Dorothy Burlingham from 1925 on represented both a relationship with a woman who was also a mother, and a solution to her oedipal disappointment, added to the secondary gains earned as her father's favourite daughter and support during his old age. In our view, this compromise enabled Anna Freud to end her adolescence; in other words, she put her infantile conflicts at the service of the cause of psychoanalysis thanks to libidinal compensations: playing a central role in her father's movement, taking care of children (whether or not they were her patients), being a substitute mother, all the while maintaining strong oedipal ties with her father, who accepted and even favoured this situation by discouraging her suitors (Ernest Jones and Hans Lampl, for example). This narcissistic compensation, i.e. the recognition of her value, even if it meant rivalry with her peers, helped her give up masturbation and beating fantasies.

At the end of the 1920s, her emotional life became more stable, and her reactions to what she felt was criticism of her father (for example in his dispute with Otto Rank) became less passionate. Her calm determination during her father's recurrent bouts of illness seem to show that she had become less tormented, more self-assured. Young-Bruehl (1988) considers that at that time, Anna succeeded in finding a solution, a positive elaboration of her adolescent conflicts. She was nearing thirty-five. Much later, looking back on that period, her friend Kata Levy wrote to Anna that it was then that "[she] became grown-up" (Young-Bruehl, 1988, p.195).

This sublimation seems to have replaced the masochistic daydreams, while her sexual abstinence seems to have been offset by her friendship with Dorothy Burlingham and the care of children and adolescents. A life project was in the making (Houssier, 2010).

Let us now return to the first period of elaboration, during the Viennese period, when personal life was closely intertwined with theoretical advances.

\section{Ramifications in the elaboration of a theory of adolescence}

\section{A rite of passage: Junius Brutus saves his son}

As she was terminating her first analysis, Anna gave up teaching to embrace the career of psychoanalyst. For some time, she had been translating her father's works into English. In 1921, on her own initiative, the first text not written by her father she chose to translate - this time from English into German - was an article by Ernest Jones on the problems of adolescence (Jones, 1922).

On May $31^{\text {st }} 1922$, Anna Freud presented a paper for admission to the Vienna Psychoanalytic Society. That same year, the Vienna Society also admitted Siegfried Bernfeld and August Aichhorn - with Anna, three founding figures of the psychoanalysis of adolescence, with three pioneering papers. Anna's essay (Freud A., 1922) was actually written six months before she received her first patient (Young Bruehl, 1988, p. 103; Sayers, 1991). Anna Freud's biographers (Young-Bruehl, 1988, Sayers, 1991) agree 
that this fictitious patient was most certainly herself. If we follow this assumption, then Anna identified her first daydreams as having begun between the ages of eight and ten, but the stories imagined by this "screen-patient" became more complex around the age of fourteen or fifteen.

At her presentation before the society in 1922, Freud had his own daydream: he saw himself as Junius Brutus having to judge his own son (Young-Bruehl, op. cit. p.108). Not only did Freud compare his daughter to a man going through a rite of passage, but Junius Brutus's son was executed after his father had ruled against him in the Roman tribunal. Here, on the contrary, Freud, who long ago had regretted this sixth child, now had the opportunity to defend her against the attacks of others, thus playing the heroic role of saviour. In this fantasy scenario, there are no female characters. Similarly, in her article, Anna Freud describes her "patient's" first love object as being the father; her mother is never mentioned. In the same way, Anna never mentions either her mother or Minna when speaking of her father's illness, beginning in 1923.

At the presentation, Siegfried Bernfeld perceived the significance of Anna's first paper: he commented that the young patient may have chosen her story material for the enlargement of her ego, in the sense of an omnipotent wish-fulfilment and typical adolescent creativity, which he called the "genius form" of adolescence (Bernfeld, 1995, p.64). Another analyst suggested on the other hand that the girl she had written about was a person "whose incompetence and inferiority would absolutely emerge in real life"' (Young-Bruehl, 1988, p.108).

Nevertheless Anna Freud in her paper saw another outcome for her "patient": the sublimation of her oedipal conflicts should enable her to find an occupation valued by society. The oedipal scar - of which the beating fantasies are the regressive "precipitations" - are transformed into a narcissistic advantage, making it possible to bear the repressed and/or sublimated tendencies (Young-Bruehl, 1988, p. 109). Her sexual asceticism then found a compensation, which could be understood as a reaction formation: the feeling of inferiority tied to the persistence of infantile wishes was offset by the advantage of being her father's daughter, his representative in the psychoanalytic movement, and the foremost pioneer of child psychoanalysis.

Anna Freud's professional success through sublimation went along with a typically adolescent defence mechanism, which she describes in her main work: permanent asceticism (Freud A., 1936). Her sensual love for her father was sublimated into a tender friendship while the beating fantasies went along with a masculinity complex, maintaining her infantile bisexuality. To be more precise, one can make the assumption of a mobility of bisexual identifications, with blurring of sexual difference, the latter resulting from a refusal of the castration complex and recourse to perverse substitution fantasies. Thus, in the beating fantasy, the little girl becomes a boy (Freud, 1919). For Anna, at the age of 27, sublimation came with asceticism, recurrent bouts of anorexia and an oedipal proximity with her father. Anna's investment of the psychoanalytic theory went along with her staying away from men; Freud's (1911) definition of the word "asceticism" could very well echo what he felt about Anna: "It would be appropriate to support those who are willing to undergo their way through hardship to knowledge". Sublimation through writing meant permanent asceticism, or the sacrifice of femininity.

In the more recurrent phases of this fantasy scenario, substitutions include the displacement of object representations onto different characters: thus, the father figure is replaced by that of the teacher - but wasn't Freud often called "Herr Professor"? While the beating scene often takes place in a school. If we briefly recall the three parts of the fantasy described by Freud - the father is beating the child that I hate; I am being beaten by my father; I am watching other children being beaten - we may note that the third part brings in a teacher who punishes or humiliates boys, who are in the girl's fantasy substitutes for her own self. In this context, being beaten in fantasy triggers masturbation. The development and intensity of these daydreams then take on a specific function: "to make possible a feeling of satisfied excitation, even though the masturbatory act was abstained from" (Freud, 1919, p.190). Disguising one's presence by changing the hero's sex follows Anna's masculinity complex, leading to satisfaction within and by way of the daydream. The young men in the daydream are typical figures of adolescent heroic figures. The "age of puberty" (Freud, 1919, p.192) is indeed decisive as to what will become of these potentially perverse positions: if there are obstacles, the attempt to find a sexual object outside the family fails, giving way to the infantile fixation. Anna's daydreams with male heroes and beating fantasies directly echo her father's discoveries. Freud thus wrote about the outcome of this fantasy construction in terms of the difference between the sexes: "By the same process, on the other hand, the girl escapes from the demands of the erotic side of her life altogether. She turns herself in phantasy into a man, without herself becoming active in a masculine way, and is no longer anything but a spectator of the event which takes the place of a sexual act." (Ibid. p.199).

If we consider this article as being inspired by his daughter's analysis, we see that Freud does not so much suggest here a "hiding place" of the libido (Freud, 1912, p.102) to counter masculine homosexual identification, or in defence against the oedipus complex; he emphasizes rather the idea of a generalized suppression of all forms of direct genital sexuality in connection with an intense fantasy life. This struggle against the fulfilment of extremely passionate post-pubertal sexual drives is central to Anna Freud's (1936) most important work of the Viennese period.

\section{Hatred and altruistic surrender in a young schoolteacher}

Anna Freud developed her clinical practice with children and adolescents (Heller, 1990) along with her theoretical work. In 1935 , she was labouring on what became one of her main works, "The Ego and the Mechanisms of Defence" (1936), closely studying puberty as a time when the drives flare up for the second time. She wrote to Max Eitingon that her work was meant to represent 
a theoretical basis for her thoughts on puberty, which she had already developed in other lectures (Freud A., 1930). The fourth and strongest part of her book, devoted to puberty, attracted most notice, and it is probably closest to her own analysis. She describes here the notion of "altruistic surrender", which Freud had termed "retiring in favour of someone else" (Freud, 1920, p. 159), as well as that of "identification with the aggressor".

In this book, she introduces the case of a young schoolteacher. According to some biographers, among whom Raymond Dyer (1983), it would seem that Anna described herself once again in this young schoolteacher, fourteen years after her 1922 paper. She had actually been a schoolteacher and founded a psychopedagogical school [33]. In the introduction to the chapter on "altruistic surrender", she mentions the schoolteacher's two main childhood wishes: to wear beautiful dresses and have many children. Both wishes were indirectly fulfilled: single and childless, she describes herself as a person governed by repression and reaction formations, a latency child who has remained attached to past conflicts. Her interest in the sexual lives of others, her talent as a matchmaker, interest in other women's clothing and especially in other women's children dominated her personal and professional life. Her apparent lack of ambition was displaced to ambition for others, those whom she loved, and this may have given the impression that she did not want anything for herself. "She lived in the lives of other people, instead of having any experience of her own" (Freud A, 1936), echoing her father's letter chiding her for not enjoying life as other girls of her age.

Though defensive, Anna Freud's lucidity is striking: "Her penis wish, with its offshoots in the shape of ambitious masculine phantasies, was prohibited, so too her feminine wish for children and the desire to display her, naked or in beautiful clothes, to her father, and to win his admiration. But these impulses were not repressed: she found some proxy in the outside world to serve as a repository for each of them." (ibid, p.125).

The masturbatory daydreams are threatened by the emergence of more directly incestuous fantasies, which cannot be displaced.

One event in Anna Freud's life illustrates "altruistic surrender": when she was thirteen, she was intensely jealous and hateful of her sister Sophie, who was courted by a boy she liked. She transformed this resentment into making her older sister even more beautiful. The substitute satisfaction received in this way enabled her to blot out the resentment and humiliation she felt. Finding one's wishes expressed by another person makes it possible to avoid one's own hostile feelings; these are repressed through "sympathetic" identification with a rival. By displacement, the schoolteacher's present friendships represent the sister whose beauty resulted in a transformation of her penis envy during adolescence. "Her altruistic surrender was a method of overcoming her narcissistic mortification" (Freud A, op.cit., p. 131).

Through the case of the young schoolteacher, Anna Freud might have been offering a reflection of the woman she herself became following her adolescent conflicts. Altruistic surrender and devotion to her father, resulting in self-abnegation and selfsacrifice, became a stumbling block $\mathrm{P}$; the adolescent project - to leave the family and pursue one's life outside the family circle - was instead turned inwards, fixated on an oedipal love object and on the creation of an extended family. Seen from this perspective, her analysis contributed to the continuation of her incestuous attachment while finding a pro domo compromise. The incestuous conflict found a resolution through sublimation in the continuation and defence of her father's work.

\section{From life to theory: adolescence through defence mechanisms}

In this part, we will take a look at a few notions developed by Anna Freud, which can be seen as linking together her personal life and work even if their autobiographical roots have become less visible over time. The concepts that emerged during the Viennese period seem very much tied to the way she experienced her adolescence: a struggle against masturbatory wishes and post-pubertal genital sexuality, through asceticism and an intellectual investment in psychoanalytic theory.

\section{Facing the danger of drive impulses}

Both in her theorisations and in her father's, adolescence is described as the ultimate stage of psycho-sexual development. Adolescent drives give rise to specific defence mechanisms, and adolescence can be seen a psychic defence crisis. In the chapter entitled "Instinctual Anxiety during Puberty", Anna Freud (1936) investigates a specific point of her theory of the Ego, centring on the mechanisms of defence she considers crucial at this time of intense drive forces. These mechanisms are first and foremost asceticism and intellectualisation.

Anna Freud describes asceticism during adolescence from a phenomenological, objective and descriptive angle, and does not devote much attention to object-choice conflict, particularly as concerns the mother figure. Asceticism is a defence mechanism of the Ego, aiming to control the drives (or "instincts" in the 1937 English translation quoted here) in their bodily expression. As she writes, "the indirect effect of the intensification of instinctual impulses is the redoubling of the subject's efforts to master the instincts" (Freud A, 1936), in a movement of excess. "Every time the instinct says 'I will', the ego retorts 'Thou shalt not" (ibid., p. 154). This attitude of the adolescent's ego resembles that of a strict parent. But for Anna Freud, the adolescent fears his drive impulses and this fear can extend to all needs, even the most basic, most ordinary physical needs.

Contemporary authors have explained this observation of adolescent asceticism, in particular as concerns anorexia, as corresponding to a vital necessity: by refusing to eat, the troubled adolescent finds a way to preserve a sense of coherence and existence (Kestemberg, 1962). Anna Freud extends her observation to adolescents who are driven through asceticism to an attitude of total deprivation as a form of "repudiation of the instincts". However, adolescent asceticism differs from neurotic attitudes of refusal (hysteria, phobia, obsessions), whose symptoms are signs of a compromise between prohibition and drive impulses. Here, we do not have repression, but the 
reversal of the defence mechanism into its opposite, leading to an excess of drive impulses; the adolescent no longer observes the constraints of external reality. When the ego continues to repudiate the instincts, without reversal, then the mechanism can lead to a form of psychosis. Asceticism appears to be founded on a process that is more primitive than repression. One could see it as an archaic, ancestral, phylogenetic trace of the ego's hostility towards the drives. The defence mechanism appears then as the expression of the intensity of the drives and their threat to the ego.

\section{Another inhibition: intellectualisation}

In the same way as asceticism is a mechanism aiming to control the drives at the body level, intellectualisation is the expression of a defensive mechanism aiming to control the drives in the realm of thought. Adolescent intellectualisation is "an indication of a tense alertness for the instinctual processes and the translation into abstract thought of that which they perceive" (ibid p. 162). Adolescents thus export into the outside world the perception of the new demands of the id; they translate drive processes into intellectual language in an attempt to master them. Anna Freud refers to the links between affects, drives and representations leading to the process of intellectualisation of instinctual life. The drives are controlled by "connecting them with ideas which can be dealt with in consciousness" (ibid. p. 163). However, more than just the mastery of drives through intellect, this psychic work,- "one of the most general, earliest and most necessary acquirements of the human ego" (ibid, p. 163), represents an activity of symbolisation that gives meaning to these anxiety-ridden sensory experiences.

In the same way that the child's intellectual curiosity is a response to his quest for answers to the enigma of sexuality Anna Freud is alluding here to the epistemophilic drive -, this period of intense psychic activity is followed by prohibition and a relative stagnation of intellectual activity. During the latency period, recourse to abstraction is unnecessary since the ego is not seriously threatened by the drives. During pre-puberty, returning sexual drives forcing through the barriers of repression generate new interest in intellectual activity.

Asceticism and intellectualisation are both part of a third mechanism - identification. "These passionate and evanescent love fixations are not object relations at all, in the sense in which we use the term in speaking of adults. They are identifications of the most primitive kind, such as we meet with in our study of infantile development, before any object love exists." (ibid. p. 169). This identification tendency takes the form of regression in adolescents: "the adolescent is in danger of withdrawing his object libido from those around him and concentrating it upon himself; just as he has regressed within the ego, so he may regress in his libidinal life from object love to narcissism. He escapes this danger by convulsive efforts to make contact once more with external objects, even if it can only be by way of his narcissism, that is, through a series of identifications." (ibid, p. 171). This description is reminiscent of Anna Freud's identification with the imaginary/fantasy couple formed by her father and Lou AndreasSalomé.
Anna Freud clearly describes the role of identification in the love life of adolescents, underscoring its narcissistic aspects. Identification enables the adolescent to preserve some control over object relations at the time of narcissistic withdrawal: identification prevents massive narcissistic regression. When the libido is withdrawn from parental objects, the ego suffers a loss, due to its being detached from the superego and parental identifications.

In addition, during puberty, the drives' devastating force can threaten more or less durably the defences of the ego, thus leading to a psychotic breakdown. We have here a psychodynamic model of adolescence seen as a moment of developmental fragility, a time of danger, similar to André Green (1989) termed "psychotic-like": a turning point which can give rise to grave psychopathological disorders, the developmental breakdown of the child becoming an adolescent. But beyond this, Anna Freud describes puberty as an opportunity for regression: the threatened ego regresses to investments which are more narcissistic than object oriented. In this context, she does not consider object libido as particularly significant in love relationships during adolescence.

\section{After Vienna: transmission and heritage in the psychoanalysis of adolescents}

\section{A historical moment (1958)}

Despite her interest in her adolescent patients before World War II, after 1936 Anna Freud did not write again on the subject until 1958. Indeed, before the war, literature on the subject of adolescents usually portrayed them as potential delinquents, always acting out and unable to work things through. The view, frequently expressed at the time, that some types of patients were not accessible to analysis, also explained the lack of knowledge on the subject of adolescence.

Twenty-two years later, Anna Freud's (1958) article “On Adolescence" began with an observation: the study of adolescence has not been satisfactory. The failure to establish a body of theory on adolescence was due among others to the fact that very few psychoanalysts practiced psychoanalysis with adolescents.

The 1958 article is based on already extensive clinical experience, especially with children (the Hampstead Nurseries, between 1940 and 1945, with Dorothy Burlingham, and of course the Hampstead Child Therapy Clinic), but also with adolescents. The paper clearly shows how her thinking has evolved over the years, in particular the increased emphasis on the object, object-relations and internalised interpersonal relationships, a perspective that can easily be tied to psychoanalytic developmental psychology. The tone of the article is very different from that of the 1936 opus. Anna Freud has become more familiar with adolescent psychology and psychopathology, in the sense that she draws the outline of what is becoming a specific psychoanalytic approach to adolescence, no longer seen as merely the terminal phase of childhood. Adolescence is viewed as a structural time of life, a key moment in the destiny of the drives. Even if Anna Freud still considers adolescence to be a normal developmental disturbance, she shines a new spotlight 
on the issue, in the sense that she encourages analysts to develop a new approach, thus preparing the foundations of today's psychoanalytic theory of adolescence.

The article addresses the relationship with infantile love objects and the consequences of the modification of the drives at puberty. Both these issues are seen today as paradigmatic of adolescence, not separately (as she presents them) but closely linked together and intertwined in the psychic work of separation from parent figures - in itself a sensitive issue in her own personal life. The relationship with objects addresses the place of internal objects. In this context, the struggle against the drives and the sexed body causes anxiety, fantasy life becoming in itself a source of conflict. Masturbatory daydreams of adolescence are a form of defensive narcissistic withdrawal in the face of genital adolescent sexuality. This struggle against the sexed body ties in with the masculinity complex and refusal of the feminine body.

Anna Freud illustrates this point of theory with a note on a case of anorexia, showing the decisive role of genitality at the time of adolescence, with the arrival of possible motherhood. The adolescent is troubled not only by the transformations of puberty, but by the re-emergence of pre-oedipal and oedipal fantasies in a new context of possible accomplishment. This situation is radically novel since until then the child had been protected by his functional immaturity against incestuous and parricidal wishes. The adolescent, feeling threatened by the possible accomplishment of these fantasies, now experiences her psychic life as dangerous and tries to escape it. Anorexia, for example, can be seen as a struggle against fantasies of oral impregnation revived by the girl's new potential for motherhood. She then rejects identification with the mother, which in turn increases the anxiety tied to the elimination of the rival parent. In such cases, anorexia can lead to a deep sense of loss of identity.

Anna Freud's new insights also include an interest in the preoedipal aspects of adolescence: in contrast with the absence of her own mother in most of her correspondence, she highlights the importance of the primary relationship with the mother. The integration of this primary internal object makes it possible for adolescents to disinvest this relationship in order to reinvest their libido in external objects. She thus shows that renouncing infantile attachments cannot be taken for granted, that the process rests on a strongly invested preliminary relationship between mother and child.

Anna Freud underscores the importance of fantasies during adolescence. She highlights the danger represented by the confrontation between newly acquired genital demands and infantile oedipal objects. These oedipal fantasies, which had apparently disappeared but were only repressed during the latency period - indeed the subject of her first article (Freud A. 1922) are now experienced as threatening. Although she addresses the issue from the angle of the ego's defences against anxiety, rather than as a process, her work opens a new perspective on adolescence combining both pre-oedipal and oedipal aspects.

Her study of psychopathology enabled her to introduce the concept of a "breakdown" in the adolescent's psychic development, a concept which was further developed and theorised by Moses Laufer (1984). Her notion of "emotional surrender", underlying the confusion between internal and external worlds and leading to loss of identity, was extensively used by Eglé and Moses Laufer to define the psychotic breakdown of adolescents faced with the impossible task of integrating their sexed, genital body.

From a therapeutic perspective, the model of treatment of adolescents favoured by Anna Freud involved taking into consideration not only the practical aspects of the child's daily life - a stance which opposed her to Melanie Klein, - but also their human environment, i.e. parents and/or caretakers.

\section{The psychotherapy of adolescents}

For Anna Freud, several factors explain the difficulty for analysts to develop a metapsychology of adolescence, and most specifically, the difficult question of transference: indeed, the rebellion usually directed towards the parents is redirected in the transference towards the analyst, with the concomitant risk of a break in the treatment. When the adolescent does establish a transference, it is a sort of "love at first sight" phenomenon, where the adolescent cannot tolerate frustration and tries to find immediate gratification in this new relationship, instead of seeing it as a source of insight. The risk of a confusion between fantasy and reality in the imagined relationship between psychoanalyst and patient is very high: words then become a source of displeasure or fear, leading the adolescent to act out and break off the treatment. Anna Freud explores here what she herself was unable to experience: the possibility of breaking off with her analyst, her father.

Today, we can take stock of what has been achieved in this field. First of all, acting out, even if it does involve breaking off the treatment, is no longer considered as something which cannot be dealt with in therapy. Next, the lack of investment on the part of the adolescent is seen as the effect of the excess of excitation caused by the strength and immediacy of the adolescent's transference (Marty, 2007). The consequence of these observations has been the adaptation of the setting to the specificity of adolescence. The approach suggesting that the treatment should be limited, in the sense that no attempt be made to obtain modifications through the analysis of unconscious material, remains relevant. Historically, the specificity of the psychotherapy of adolescents, as well as borderline patients, has led to the reassessment of the setting and therapeutic techniques, a need recognized today after sixty years of theoretical and clinical trial and error. In anticipation of the theorisation which blossomed in the 1960s (Houssier, 2007), Anna Freud's views on adolescence underwent considerable modification. In her own self-analysis, following her analysis with her father, she calls up her adolescent memories to explain opposition to ideal parental values. Anna Freud's own cultural ideas and objects, poetry and music, which were different from those of her parents, contributed to her process of individuation during adolescence (Freud, A, 1966).

In a 1968 article on "Acting Out", devoted in part to the treatment of adolescents, her changing position shows a shift 
away from pessimism towards a discreet but nevertheless significant elaboration. Thus, she reflects on the possibility of using acting out in the transference, interpreting it as a return of past tendencies as well as an attempt to reach outside the family circle (Freud A. 1968). The propensity of adolescents to act out their conflicts instead of talking about them is no longer seen as simply the reflection of narcissistic tendencies; it is interpreted rather as a gesture addressed to the object and a way of remembering, following in this Freud's view on acting out in the analytic context (Freud, $1914 \mathrm{c}$ ).

\section{Transmission in the psychoanalysis of adolescents: Anna Freud's legacy}

Anna Freud's 1958 article marked a turning point in the elaboration of the psychoanalytic theory of adolescence - indeed, the same title was chosen by Jeanne Lampl-de-Groot (1960) for her article and by Peter Blos (1962) for his book "On Adolescence". Anna Freud raises the question of the definition of adolescence, beyond psychopathology or developmental issues, entrusting the task of elaborating the metapsychological foundations of the adolescent process to the second and third generation of psychoanalysts. As it turned out, almost all the pioneers of the psychoanalysis of adolescents, except Winnicott, belonged to the Annafreudian trend. The movement was initiated in the 1960s, in France by Pierre Mâle and Evelyne Kestemberg, in the United States by Peter Blos, Erik Erikson and Kurt Eissler, and in Great Britain by Moses Laufer. François Ladame (2008), who belongs to the school of Moses and Eglé Laufer, recently expressed an interesting point of view ${ }^{1}$ on the deeper sources of their work: in his view, Freud did not so much fail to analyse his daughter, as he did her adolescence. Ladame's hypothesis is the following: Anna Freud's unconditional support for Laufer's work on adolescence might have been rooted in Anna's unresolved adolescent conflicts. From her insistence, Moses Laufer derived the conviction that one could not analyse adolescents if one had not analysed one's own adolescence. This question leads to the issue of Freud's own adolescence and self-analysis, with the possibility that Freud's adolescence may not have been as "quiet" (De Mijolla, 1996) as might have been surmised. Kurt Eissler (1978) counters this more official version supported by Ernest Jones, among others. He suggests that like all creative persons, Freud had had a difficult adolescence, and that one of the main triggers of his adolescent conflicts was a traumatic disappointment in love. Eissler's hypothesis is that this disappointment led to a defensive organization and the repression of his adolescent drives, similarly to what later happened for Anna.

During the thirty years she spent working at the Hampstead Child Therapy Clinic, Anna Freud, along with her colleagues, developed a technique of observation and data collection concerning the psychoanalytic treatment of children and adolescents, with a view to evaluating the degree of maturation of the ego. They created the now famous indexes, which contained clinical notes on each child and adolescent, making it possible to discuss the technical and theoretical aspects raised by each case (Sandler, 1962). These indexes also made it possible to coordinate the work of the different therapists caring for child and mother, for example.

This model, based on the alliance between psychoanalysis and pedagogy, has been adopted today in numerous child guidance centres and other public institutions in France with the support of psychiatry. In France, this alliance is apparent in the very designation of some institutes as Centres Médico-PsychoPédagogiques. One of the main therapeutic tools is the practice of family, or parental, consultations, which take into account the parents' narcissism, an important factor in the psychic make-up and symptoms of adolescents. These consultations are also justified by the wish to protect the psychotherapy and psychotherapist from parental intrusion. Clinical experience has confirmed this concern: in her article, Anna Freud (1958) writes that parents must cope with difficult moments when they see that their child is changing; this has an influence not only on the child's relationship with each of his parents, but also on the entire family group and underlying fantasies. Beyond their role of "resounding box", family consultations can also help parents work through and modify their parental positions thanks the psychotherapy of their child.

Today, thanks to Anna Freud's work and influence, the psychotherapy of adolescents has become a widespread practice [31]. Many different forms of psychotherapy have emerged, and the creativity observed in this field matches the variety of issues raised by adolescents. Instead of expecting adolescents to fit the model of the analytic cure, psychoanalysts have adapted their practice to the wide range of situations encountered, from normal to pathological. The development of different clinical settings psychotherapy, "bifocal" therapy (i.e. therapy conducted by two therapists) or family therapy, psychodrama, psycho-pedagogical approaches [37] has confirmed Anna Freud's viewpoint: adolescence plays a distinct and specific role in psychoanalytic theory and practice.

\section{(Translated by Zoe Andreyev)}

\section{References}

1. J. André, C. Chabert, La psychanalyse de l'adolescence existe-t-elle ? [Does the psychoanalysis of adolescents exist?] Paris, PUF. 2011.

2. Blos P. On adolescence : A psychoanalytic interpretation. New-York : The Free Press of Glencoe. 1962.

3. Burlingham M J. The last Tiffany. A biography of Dorothy Tiffany Burlingham. New-York: Atheneum. 1989.

4. Mijolla A. Quiet teenager: S. Freud. A quiet teenager: Sigmund Freud Les Cahiers du College International Adolescence. 1996;1:231-267.

5. Dyer R. The work of Anna Freud. New-York: Aronson. 1983.

6. Eissler K. Creativity and adolescence : the effect of trauma in Freud's adolescence. Psychoanal Study Child. 1978;33:461-517.

7. Freud A. Letter to Ernst Freud, 2 February 1919. Freud Museum: London. 1919.

8. Freud A. Beating Fantasies and Daydreams. In : The writings of Anna Freud. Vol. 1: Introduction to Psychoanalysis, p. 137-57. New-York International Universities Press. 1966-1980. 
9. Freud A. Introduction to psychoanalysis : lectures for child analysts and teachers. New-York: International Universities Press. 1974.

10. Freud A. The Ego and the Mechanisms of Defence. Karnac Books, London, translated by Cecil Baines. 1937, 1966.

11. Freud A . Adolescence. Psychoanal. Study Child. 1958;13:255-278.

12. Freud A. Adolescence as a developmental disturbance. New York Basic Books. 1969;115.

13. Freud A. On losing and being lost. Psychoanal Study Child. 1967;22:919.

14. Freud A. Problems of Psychoanalytic Training, Diagnosis, and the Technique of Therapy. International Universities Press. 1968;7:94109.

15. Freud S. Excerpts from the Fliess papers. Letter 69. 1897;1:259-260.

16. Freud S. Sexuality in the aetiology of the neuroses. 1898;3:261-285.

17. Freud S. The interpretation of dreams. First part. 1900;4:1-338.

18. Freud S. Fragment of an analysis of a case of hysteria. 1905;7:3-122.

19. Freud S. Three essays on the theory of sexuality. 1905;7:125-243

20. Freud S. Analysis of a Phobia in a Five-Year-Old Boy (Little Hans) 1909;9:1-130.

21. Freud S (1911). Contribution to a Memorandum of the Society for the support of Jewish Students without Means (Verein zur Unterstützung mitteloser israelitischer Studierender) in Vienna, published by the Board of the Society, edited and introduced by G. Fuchsgelb, Vienna. 1911; pg-27.

22. Freud S. The dynamics of Transference. 1912;12:98-108.

23. Freud S. On the history of the psycho-analytic movement. 1914;14:766.

24. Freud S. Remembering, repeating and working through (further recommendations on the technique of psycho-analysis II) 1914;12:147-156.

25. Freud S. "A child is being beaten": A contribution to the study of the origin of sexual perversions. 1919;17:175-204.

26. Freud S. The Psychogenesis of a Case of Homosexuality in a woman 1920;18: $145-172$

27. Freud S. Some psychical Consequences of the Anatomical Distinction between the Sexes. 1925;19: 243-258.

28. Green A. Point de vue du psychanalyste sur les psychoses à l'adolescence, [A psychoanalyst's point of view on psychosis during adolescence] in F. Ladame, P. Gutton, M. Kalogerakis, Psychose et adolescence [Psychosis and adolescence] Paris, Masson. 1989;232244.
29.P. Heller. A Child Analysis with Anna Freud, Madison, Conn. International Universities Press. 1990

30. Heller P. Anna Freud's letters to Eva Rosenfeld. Madison: International Universities Press. 1992.

31. Houssier F (2009). Réflexions sur la délinquance et la psychothérapie chez les auteurs inspirés par Anna Freud (1945-1965) : émergence des premières théories de l'adolescence [Thoughts on delinquency and psychotherapy in the works of authors inspired by Anna Freud 19451965: emergence of the first theories of adolescence] in Psychiatrie de l'Enfant, 2009;52(2): 593-623. DOI : 10.3917/psye.522.0593

32. Houssier F (2010). L'école d'Anna Freud. Créativité et controverses. [Anna Freud's School: Creativity and Controversies] Paris : Editions Campagne Première.2016.

33. Jones E. Some problems of adolescence. In : Papers on psychoanalysis, 389-406. Bailliere : Tyndal et Cox. 1922.

34.E. Kestemberg, L'identité et l'identification chez les adolescents. Identity and Identification in adolescents in L'adolescence à vif, Paris, PUF. 1999:7-96.

35. Lampl de Groot J. On adolescence. Psychoanal Study Child. 1960;15:95103.

36. Ladame F. Colloque "Penser la psychanalyse de l'adolescence". University of Paris-Diderot.

37. Marty F, Houssier F. Eduquer l'adolescent ? Pour une pédagogie psychanalytique. Educating adolescents? In favour of psychoanalytic pedagogy. 2007.

38. Masson JF. The Complete Letters of Sigmund Freud to Wilhelm Fliess 1887-1904. London: The Belknap Press of Harvard University Press. Editor. 1985.

39. Pfeiffer E, Sigmund Freud and Lou Andréas-Salomé: Letters. London : The Hogarth Press. Editor. 1972.

40. Pragier G, Faure-Pragier S. Une fille est analysée : Anna Freud. [A daughter is analyzed: Anna Freud]. Rev Fr Psychanal. 1993;2(57): 447-458.

41. Rothe D A, Weber I. As if I were coming home to my father and sister. The Lou Andreas-Salomé-Anna Freud correspondence (1919-36) Göttingen: Wallstein Verlag. Editors. 2001.

42. Sayers, Janet. Mothers of Psychoanalysis: Helene Deutsch, Karen Horney, Anna Freud, Melanie Klein. New-York: W.W. Norton. 1991.

43. Young-Bruehl E. Anna Freud: A Biography. New-York: Summit Books. 1994.

44. Houssier F. La puberté psychique : premières esquisses. Le tourment adolescent, The torments of adolescence. Paris: PUF. 2007:53-81. 